Meta

Journal des traducteurs

Translators' Journal

\title{
Consecutive Interpretation Training: Videotapes in the classroom
}

\section{Nancy Schweda-Nicholson}

Volume 30, numéro 2, juin 1985

URI : https://id.erudit.org/iderudit/003731ar

DOI : https://doi.org/10.7202/003731ar

Aller au sommaire du numéro

Éditeur(s)

Les Presses de l'Université de Montréal

ISSN

0026-0452 (imprimé)

1492-1421 (numérique)

Découvrir la revue

Citer cet article

Schweda-Nicholson, N. (1985). Consecutive Interpretation Training: Videotapes

in the classroom. Meta, 30(2), 148-154. https://doi.org/10.7202/003731ar d'utilisation que vous pouvez consulter en ligne.

https://apropos.erudit.org/fr/usagers/politique-dutilisation/ 


\title{
CONSECUTIVE INTERPRETATION TRAINING : VIDEOTAPES IN THE CLASSROOM
}

\author{
NANCY SCHWEDA-NICHOLSON
}

\section{INTRODUCTION}

Much has been written on consecutive interpretation pedagogy ${ }^{1}$; however, to the best of this author's knowledge, the use of videotapes in consecutive interpretation training has not been treated in the scholarly literature.

Consecutive interpretation training teaches the student to discern main ideas and follow trends of thought patterns. Moreover, it helps him/her to develop a coherent and personal note-taking system. An important adjunct to note-taking and note-reading techniques is training in public speaking skills, which are critically important for the consecutive interpreter. In addition to presenting complete and accurate information, the trainee must learn to express him/herself clearly, speak with a steady, wellmodulated voice and at a normal rate of speed, be poised, self-confident, and maintain good eye contact with the audience. Moreover, students should be aware of consecutive interpretation procedures in the courtroom and how they differ from those in a conference situation.

As our society grows increasingly complicated and more technologically oriented, it is important for interpreter trainers to take advantage of the newest and most advanced teaching tools available. Videotapes were incorporated into the University of Delaware Interpretation Program four years ago. They constitute an integral part of our consecutive training.

The current paper discusses five ways in which videotapes can prove invaluable in the consecutive interpretation classroom. Videotapes illustrate 1) students' personal styles as well as their public speaking skills; 2) note-taking and note-reading techniques ; and 3) court interpretation. Fourth, videotapes of lectures by University professors and guest speakers are used to expose students to a wide variety of speech styles and disciplines. Fifth, the Program utilizes videotapes of various escort assignments which clearly demonstrate the problems that can arise during the course of such assignments. (Near the end of their training, students write and act in escort situations and often highlight the differences between good and bad interpretation.) The paper concludes with a discussion of student reaction to videotape use in consecutive training.

\section{PUBLIC SPEAKING SKILLS AND PERSONAL STYLE}

To teach or strengthen public speaking skills, videotapes are used in a number of ways at Delaware. For example, students listen to the instructor or another student give a short speech and take notes accordingly. (The original speech may or may not be videotaped.) After the speech, the students have a few brief moments to look over their notes and then, one by one, each gives his/her interpretation while being videotaped. After each trainee finishes, the tape is played back and the instructor critiques the qual- 
ity of the interpretation. After the instructor has made his/her comments, the other members of the class are encouraged to comment as well. Both strong and weak points are highlighted during the critique sessions. The students are judged not only on their overall delivery (e.g., eye contact, voice modulation, poise and assured manner) but also on correct ordering, completeness, and fidelity of the message. (In testing situations, of course, each student is taped individually with no audience, because students will all be interpreting the same speech. Consequently, those who are not first would have the advantage of listening to several renditions before it was their turn to interpret.)

The technique of videotaping and critiquing public speaking skills should be used initially quite early in the consecutive training process. In this way, it helps each student to immediately identify his/her strong and weak points with respect to personal style. Certainly, one can tell students "You were too tied to your notes" or "You often seemed flustered and unsure", but we have found that there is no substitute for showing them a tape of their performance. It provides them with the opportunity to see themselves just as the audience sees them. From the start, then, students are aware of areas that need more attention.

Some of the most common problems identified by this videotape method are : 1) students are inordinately tied to their notes and, consequently, make little, if any, eye contact with the audience; 2) students speak haltingly and, quite often, unnaturally slowly ; 3) students do not speak loudly enough ; and 4) students are so conscious of the desire to relay information correctly and completely (which, of course, is primary) that they are unaware of a monotonous, lifeless tone of voice.

Furthermore, when unsure of a particular point of information, some students swallow their words. Another manifestation of uncertainty is speaking very quickly, perhaps hoping no one will understand. As a rule, these mannerisms are cover-up tactics.

A few students have a tendency to express their doubts through confused facial expressions. Most trainees do not realize they exhibit this behavior when unsure and are very surprised at how they appear on the tape. This undesirable mannerism, of course, makes the interpreter appear incertain and strongly detracts from the credibility of the interpretation.

It is imperative to note here that the interpreter's verbal and non-verbal behavior contributes tremendously to the audience's impression of the speech. Even if all of the material presented by the interpreter is accurate, long hesitations, swallowing of words and confused facial expressions will most assuredly lead the audience to believe that the interpreter has not understood the original speech and is therefore conveying incorrect information and/or omitting material altogether.

\section{NOTE-TAKING AND NOTE-READING}

Another facet of consecutive interpretation training in which videotapes have proven effective is note-taking and note-reading. Before describing the training exercises used at Delaware, some general background information on note-taking and notereading techniques is in order.

To become skilled consecutive interpreters, students must develop acute powers of concentration and analysis as well as an accurate and workable system of notetaking. Each interpreter's note-taking style is intensely personal. Some interpreters rely mainly on abbreviations, capital letters and acronyms in their note-taking. Other interpreters use numerous abstract symbols, such as a square to represent "country"2, an upward-pointing arrow to represent "progress", "increase" or "development"3, and/or a pennant shape to indicate "public"4. Still others employ pictographs, such as a rapid, rudimentary sketch of an airplane to represent "aircraft" ${ }^{15}$. Symbols can be particularly 
helpful because they are not language-specific. However, if one is not accustomed to using symbols in other everyday note-taking activities, it will probably be quite difficult to develop a personal note-taking system that relies heavily on symbolic representation.

A very common problem among elementary consecutive interpretation students is the feeling on their part that taking copious notes will ensure an accurate and complete interpretation. However, this strategy usually works in just the opposite way. Students become so involved in taking down words that they are not listening for the meaning ${ }^{6}$. Consequently, when asked to interpret, the trainees often say, "I have a lot of words (notes) on my paper, but I cannot make sense of them". At Delaware, students are always encouraged to listen more and write less. We emphasize the importance of listening for the meaning first and then jotting down a word/abbreviation/symbol which will automatically trigger that meaning at the time of the interpretation.

If an interpreter has relatively few notes, eye contact with the audience will almost inevitably be strengthened, because he/she will proceed from one idea to the next with minimal time spent on note-reading. Fewer notes also contribute to greater flexibility of expression. The interpreter usually speaks with fewer jerks and starts. On the other hand, when the student interpreter takes copious notes, the interpretation very often becomes more of a reading and deciphering process than a speaking one. The student must be taught to realize that there are numerous ways to express one particular meaning. The interpreter's primary responsibility is to render the meaning of the original speech and, in this connection, the choice of words to express that meaning is quite often inconsequential. At the beginning of consecutive training, students have difficulty believing that they should be able to get along with fewer notes; however, with many opportunities to practice, most will be able to strengthen their listening, comprehension and analysis powers, work with a reduced amount of notes and, ultimately, become skilled consecutive interpreters.

Even though note-taking systems are highly personal, points such as the effective use of spacing, indentation, and indication of repetition and stress can be illustrated very well with videotapes. Many interpreters use similar structuring techniques when dealing with lists and examples, and these organizational strategies can often be presented to students through a videotaped demonstration. For example, to illustrate notetaking techniques, advanced students or interpreters who have already passed their certificate examinations take notes on the blackboard during a short speech. The entire process is videotaped. (Admittedly, taking notes on the blackboard is a bit awkward in comparison to writing on a piece of paper, but it does work out rather well.)

While listening to the speech and watching the note-taking process, elementary students are able to identify how the interpreter represents in writing the ideas he/she is hearing. The trainees see that most interpreters do not take numerous notes during a speech. Rather, they listen for and analyze the meaning before writing anything down. Students also have the opportunity to observe the effective use of spacing to separate main ideas and different parts of the speech. Trainees note the various ways interpreters indicate specific examples within general categories, numbering and indentation when lists are involved, and how an argument develops with related facts.

Proceeding to the note-reading phase, beginners see how the interpreter goes through continuous cycles of 1) looking briefly at his/her notes which evoke the meaning and 2) expressing that meaning while looking at the audience and maintaining good eye contact. After conveying one or more points of information, the interpreter then returns to his/her notes and begins this short cycle once again. Since the interpreter has understood during the note-taking process, he/she proceeds smoothly through the interpretation without long hesitations. To reiterate, the interpreter must understand dur- 
ing the original speech in order to give a complete and accurate interpretation. Lack of understanding initially results in the situation mentioned earlier, in which the student finds that he/she has many words/symbols/abbreviations on his/her paper; however, the notations are simply no more than discrete items which have no contextual coherence or meaning for the trainee.

The student interpreters have heard the entire original speech themselves, so they can follow the interpretation with a critical eye. Sometimes, there are mistakes or small errors of omission on the teaching tapes. Students are usually able to identify both the weak and strong points of an interpretation. This analytical activity helps to strengthen their acuity and perception.

\section{COURT INTERPRETATION}

Consecutive interpretation procedures in the courtroom differ from those in a conference situation. Videotapes clearly and effectively illustrate the different techniques interpreters use in the courts. For example, consecutive interpreters interpret at much shorter intervals in the courtroom. Note-taking may or may not be involved. During questioning or while an expert witness presents a prepared statement, the interpreter usually works sentence-by-sentence. If a question or sentence is particularly long, the interpreter may go clause-by-clause or phrase-by-phrase. This procedure arises out of the need for total accuracy and completeness. It is important to note that it is the interpretation (when into English in the United States) that becomes a major part of the official court record?.

The Delaware Interpretation Program uses tapes of simulated trials as well as video recordings of actual trials during which interpretation has been used. Trainees immediately recognize the differences between consecutive conference interpretation and consecutive interpretation in the courtroom. As students view the courtroom videotapes, they are able to compare the original utterance with the interpretation at once, thereby observing how the interpreter deals with the material. Moreover, trainees have the opportunity to analyze the utterance themselves and decide how they would express its meaning. Students are also aware of extra-linguistic factors in the courtroom that can affect the interpretation process. As well, students quickly realize that the court interpreter must often know a great deal of specialized vocabulary (which relates to a particular case) in addition to legal terminology. For example, one of our tapes shows a murder trial in Puerto Rico during which an expert witness (an American physician) gives testimony in English. His statements are interpreted into Spanish by the court interpreter who is seated next to him. The attorney asks his question in Spanish, which are subsequently interpreted into English for the doctor. As the doctor describes the wounds on the decedant's body, he uses terms such as "cuts", "scratches", "abrasions", "sternum", "right chest wall" and "chest cavity". This medical terminology must be interpreted accurately and completely.

Finally, students also observe how difficult it can be to work back and forth in two languages continuously. At times, it can become quite confusing and stressful.

\section{CLASSROOM LECTURES AND OTHER SPEECHES}

Beginning this year, we have added yet another videotape component to consecutive interpretation training. The University of Delaware's Instructional Resources Center has numerous tapes of classroom lectures as well as speeches given by visiting professors. The subject matter of these tapes is very diversified, which provides us with teaching tools in a wide variety of disciplines. Students are informed of the title and general content of the lecture which will be used as a forthcoming class exercise. The trainees then are instructed to research the topic on their own in preparation for the 
speech they will be interpreting. In this way, students become familiar with documentation and reference sources and are able to establish a strong foundation upon which future such research assignments can be based. Since interpreters must "know a little bit about everything", developing preparation and research skills in many areas enhances their general knowledge as well. In addition to varied subject matter, students are exposed to a broad range of speaking styles, which better prepares them for the diversity that exists. Trainees learn very quickly that there are good and bad speakers. During their training, then, students are able to develop strategies for dealing with problematic situations. In this connection, they gain valuable experience in rapidly adapting to different delivery speeds, foreign accents, etc.

\section{ESCORT INTERPRETATION PROJECTS}

The fifth and final area of consecutive interpretation training in which videotapes are extremely useful is presenting hypothetical escort interpretation situations. Toward the end of the core Program, students write and act in escort interpretation scenarios which illustrate strong and weak consecutive performance as well as numerous difficulties that can arise during the course of an escort assignment.

Several classes have created excellent scenarios comparing and contrasting different interpreters and the quality of their work. For example, one year the students very effectively illustrated differences in performance of a makeshift "interpreter" (a woman claiming to be an English speaker who volunteered to interpret for an injured Spanishspeaking player at a soccer game) and a professional interpreter (a staff interpreter at the hospital where the injured athlete was taken for treatment). This scenario clearly demonstrated the problems that can occur when an unqualified person acts as an "interpreter". The person who came down out of the stands at the stadium said that she spoke English but, in fact, she had many comprehension and expression problems as she spoke to the American physician. The injured player was decidedly very nervous and in pain but was not getting the information he needed and wanted from the interpreter. Nor was the physician receiving an accurate description of the injuries as the athlete explained them. Moreover, the "interpreter" was very excited and emotional. Her behavior seemed to contribute to greater anxiety on the part of the injured person. After the injured athlete arrived at the hospital, one observed a striking contrast between the performance of the makeshift "interpreter" and that of the staff interpreter. The staff interpreter was complete in her interpretation, had no comprehension or expression problems and knew all of the necessary medical technology. She was self-assured and poised as well as comforting to the patient. The interpreter was a professional who worked well with the X-ray technician and the physician.

Another year, students played the roles of foreign journalists and their escort interpreters at an American press conference. The interpreters interpreted simultaneously for the two journalists (one French ; the other, a Spanish-speaker from Venezuela) during the prepared statement. Afterward, during the question-answer period, the journalists each asked several questions through their interpreters. It was quite obvious that the Spanish interpreter had omitted a considerable amount of information during her simultaneous interpretation. The Venezuelan journalist asked a number of questions whose answers were part of the original statement but which the interpreter had failed to provide to her client. (For example, "Could you tell us when you expect this revolutionary product to be on the market ?" - The speaker had already stated this information.) After several such questions, the speaker became rather exasperated with the journalist at being asked to repeat so much and said in an irate tone of voice : "As I have already stated,...." The Spanish interpreter, to cover herself when interpreting these answers for her client, omitted the speaker's phrases which indicated that he had already 
included this information in his prepared statement. The Spanish interpreter also exhibited a cavalier, casual attitude toward the assignment, during both the simultaneous interpretation of the original statement and the question-answer period. On the other hand, the French interpreter was complete and accurate with dates, statistics and other critical, essential information. Moreover, his behavior was very professional throughout.

Scenarios such as those just described permit students to demonstrate what they have learned about escort work and interpretation in general. Very importantly, these tapes are used as teaching tools in subsequent classes. Interpreter trainees view the tapes and comment on attitudes, errors, omissions and overall differences in performance. In this way, students apply the theoretical material they have learned to a practical situation. From the instructor's point of view, it is very interesting to see how many of the interpreters' strengths and weaknesses the students are able to identify.

\section{STUDENT REACTION TO CLASSROOM VIDEOTAPE USE}

Overall student response to the use of videotapes in teaching consecutive interpretation has been extremely positive. With respect to teaching public speaking skills, the student sees how the audience perceives him/her and is critiqued on his/her personal style. In addition, the trainee has the opportunity to compare different versions of the same speech, which aids him/her in the continuing development of flexibility of expression. As to note-taking and note-reading, students are very interested in seeing how other people take notes and how successful their note-taking systems are. Once again, trainees are able to learn from one another. The court interpretation tapes clearly illustrate how conference and court interpretation differ. Moreover, students are able to observe various unique elements (both linguistic and extralinguistic) of the courtroom situation. Interpreter trainees value their broad exposure to numerous content areas and speech styles, which is enhanced by the use of videotaped classroom lectures and other speeches. Finally, the escort interpretation scenarios are a highlight of the semester. Students very much enjoy creating the hypothetical situations. These scenarios allow them to demonstrate what they have learned in a creative way. The trainees are always very interested in writing the skits, acting in them and, finally, seeing themselves on the tapes.

\section{CONCLUSION}

The current article has discussed five major ways in which videotapes are used in consecutive interpretation training at the University of Delaware. Student response to this teaching technique has been overwhelmingly positive. The usefulness of these training tapes can be summed up rather well by the old adage, "One picture is worth a thousand words." The tapes highlight the practical side of consecutive interpretation in conference situations, in the courts, and during escort assignments. Other interpreter trainers may wish to consider incorporating videotapes into their curriculum. They have proven themselves to be invaluable in our Interpretation Program at the University of Delaware.

Notes

1. See, for example, Déjean Le Féal 1981, Delisle 1981, Garretson 1981, Henderson 1976, Herbert 1952, Ilg 1982, Kordić 1970, Longley 1978, Paneth 1962, Rozan 1956, Seleskovitch 1975 and Thiéry 1981.

2. Rozan $1956: 35$.

3. Rozan $1956: 32$.

4. Henderson 1976 : Addendum.

5. Seleskovitch $1975: 107$.

6. Paneth 1982 : 106 makes a very brief reference to this phenomenon. 
7. At this time, only the English version is preserved for the record in the United States. However, there is currently strong support for incorporating both the interpretation into English and the original foreign language testimony (including the attorneys'/judges' questions which the interpreter interprets into the foreign language) in the official court record. In this way, the completeness of the interpreted material could be easily compared, analyzed, and verified so as to ensure an accurate record. Of course, while an accurate record does not guarantee due process of law to the non-English speaker, it is the essential basis upon which potential appeals stand.

\section{BIBLIOGRAPHY}

DÉJEAN LE FÉAL (1981) : "L'enseignement des méthodes d'interprétation", in Delisle, édit., pp. 75-98.

DELISLE, Jean, éd. (1981) : l'Enseignement de l'interprétation et de la traduction de la théorie à la pédagogie, Ottawa, Éditions de l'Université d'Ottawa.

GARRETSON, Deborah A. (1981) : "A Psychological Approach to Consecutive Interpretation", Meta 26, no 3, pp. 244-254.

GERVER, David and H. Wallace SINAIKO, eds. (1978) : Language Interpretation and Communication, New York, Plenum Press.

HENDERSON, John A. (1976) : "Note-Taking for Consecutive Interpreting", Babel 22, no 3, pp. 107-116 plus Addendum.

HERBERT, Jean (1952) : Manuel de l'interprète ( $3^{\mathrm{e}}$ éd.), Genève, Georg et Cie.

ILG, Gérard (1982) : "L’interprétation consécutive : la pratique", Parallèles 5, pp. 91-109.

KORDIĆ, Mara (1970) : "À propos de l'interprétation consécutive - Traduction orale", Babel 16, no 2, pp. 80-81, 84.

LONGLEY, Patricia (1978) : "An Integrated Program for Training Interpreters", in Gerver and Sinaiko, eds. (1978) : pp. 45-56.

PANETH, Eva (1962) : "The Interpreter's Task and Training", The Incorporated Linguist 1, no 4, pp. $102-109$.

ROZAN, Jean-François (1956) : la Prise de notes en interprétation consécutive, Genève, Georg et Cie.

SELESKOVITCH, Danica (1975) : Langage, langues et mémoire, Paris, Minard.

THIÉRY, Christopher (1981) : "L'enseignement de la prise de notes en interprétation consécutive : un faux problème ?", in Delisle, édit. (1981) : pp. 99-112. 